ШалеваO.I., volex2007@ukr.net, ORCID ID: 0000-0002-4057-2789, Researcher ID: F-4533-2019, к.е.н., дои., доцуент кафедри підприємницутва, торгівлі та логістики, Львівський торговельноекономічний університет, м. Львів

\title{
ПУБЛІЧНІ ЗАКУПІВЛІ ЯК ОСНОВА В2G-СИСТЕМИ ЕЛЕКТРОННОЇ КОМЕРЦІї
}

\begin{abstract}
Анотація. У статті досліджено сутність B2G-системи електронної комерції, визначено ії відмінності від інших споріднених систем та можливі способи господарської взаємодії державних структур і суб'єктів бізнесу. Проаналізовано сучасний стан розвитку В2G-сегмента у світі та його суб'єктний склад в Украӥні. Виявлено, щуо наймасштабнішою складовою В2G є публічні закупівлі, які здійснюються з використанням інформаційно-комунікаційних технологій. Досліджено основні правові засади запровадження публічних закупівель $в$ Украӥні, проведено аналіз основних передумов і етапів формування системи електронних публічних закупівель $i$ механізмів, які забезпечують їх ефективне функціонування, а також ресурсів, які дають змогу ознайомитися зі специфікою ї̈ діяльності та забезпечити високий рівень кваліфікачії учасників тендерів. Описано технологію функиіонування електронної системи закупівель ProZorro та ї̈ основних структурних елементів у контексті застосування гібридного (подвійного) принципу організації роботи. Вивчено аналоги вітчизняної системи електронних закупівель, які функціонують у ряді країн-членів СОТ, і зазначено про високу ї̈ оцінку світового економічного співтовариства. Досліджено функціональні переваги авторизованих торгових майданчиків, які входять до складу системи ProZorro. Охарактеризовано основні показники діяльності ProZоrro за період ї̈ функціонування в розрізі окремих напрямів діяльності як на внутрішньому, так $і$ на міжнародному ринках. Виявлено, щзо з метою популяризації електронних публічних закупівель серед потенційних виконавців і для підвищення ефективності функиіонування відповідної системи в Украӥні регулярно проводяться масштабні заходи, які дають змогу відзначати найкращих ї̈ учасників. Уточнено, щуо представники бізнес-структур на належному рівні оцінюють основні організаційні, інформаційні та технологічні механізми ProZогro, водночас визначаючи певне коло проблем, пов'язаних із функціонуванням иієё системи на сучасному етапі.
\end{abstract}

Ключові слова: електронна комерція, В2G, публічні закупівлі, тендери, електронна система публічних закупівель, ProZorro, електронний торговельний майданчик.

Shaleva O. I.,

volex2007@ukr.net, ORCID ID: 0000-0002-4057-2789, Researcher ID: F-4533-2019,

Ph.D., Associate Professor, Associate Professor of the Department of Entrepreneurship, Trade and Logistics, Lviv University of Trade and Economics, Lviv

\section{PUBLIC PROCUREMENT AS A BASIS OF B2G-SYSTEM OF THE E-COMMERCE}

\begin{abstract}
The article examines the essence of the B2G system of e-commerce, identifies its differences from other related systems and possible ways of economic interaction between government agencies and businesses. It was discovered that the largest component of B2G is public procurement, which is performed using information and communication technologies. The main legal principles of public procurement in Ukraine were studied, the main prerequisites and formation stages of the electronic public procurement system were analyzed, as well as resources that allow to get acquainted with the specifics of its activities and ensure a high level of bidders qualification. The technology of the electronic ProZorro procurement system functioning and its main structural elements in the context of the hybrid (double) principle of work organization applying are described. The analogues of the domestic eprocurement system, which operate in several WTO member countries, were studied and their appreciation by the world economic community was noted. The functional advantages of authorized trading platforms, which are a part of the ProZorro system, have been studied. The main indicators of ProZorro's activity for the period of its functioning in the separate directions of activity, both on domestic and international markets were described. It was discovered that to promote e-procurement among potential contractors and to increase the relevant system efficiency, Ukraine regularly
\end{abstract}


holds large-scale events that allow noting the best participants. It is specified that the business structures representatives properly evaluate the main organizational, informational and technological mechanisms of ProZorro, at the same time identifying a range of issues related to the functioning of this system at the present stage.

Key words: e-commerce, B2G, public procurement, tenders, electronic public procurement system, ProZorro, electronic trading platform.

\section{JEL Classification: E69, H57, H89, K39, L81, Q01 \\ DOI:https://doi.org/10.36477/2522-1205-2021-65-22}

Постановка проблеми. Функціонування державного механізму передбачає виконання ним основних завдань щодо вирішення загальнодержавних проблем і забезпечення належного соціальноекономічного розвитку будь-якої країни. Діяльність державних організацій, установ і підприємств, пов'язана із закупівлею товарів, робіт і послуг за кошти державного бюджету, забезпечується через систему публічних закупівель. Передова світова практика свідчить, що найбільш ефективно такі закупівлі здійснюються на засадах доступності, конкурентності та публічності. Така закупівля забезпечує постачання товарів, робіт чи послуг з ринковою ціною з детальним порівнянням якості, кількості, часу і місця розташування постачальника. Як комерційні, так і державні структури повинні бути зацікавленими в чесній і відкритій конкуренції та докладати значних зусиль, щоб мінімізувати ризики змови і шахрайства. Публічні закупівлі $є$ дієвим засобом державного регулювання економічного середовища. При цьому застосування сучасних інформаційно-комунікаційних технологій, притаманних електронній комерції, дає змогу забезпечити високий рівень організації всіх процесів, зробити ïx максимально ефективними та відкритими для широкого загалу. Крім того, Законом України “Про публічні закупівлі” передбачено, що основна частина закупівель здійснюється саме шляхом використання електронної системи закупівель. Саме тому аналіз сучасного стану розвитку системи публічних закупівель як складової електронної комерції дає можливість об'єктивно оцінити ефективність функціонування державного механізму та його взаємодії з суб'єктами ринку товарів і послуг.

Аналіз останніх досліджень і публікацій. Проблематика формування і розвитку вітчизняної системи публічних закупівель порушувалася в публікаціях Альцивановича О. В. [1], Джабраїлова Р. А. [2], Вареник В. М., Здирко Н. Г., Лайка О. І., Мельникова О. С. [3], Парасій-Вергуненко I. М., Русіна В. М., Севостьянової Г. С., Сошнікова А. О. [4], Ткачика Ф. П., Фаїзова А. В. Серед зарубіжних науковців слід відзначити Гелбрейта Дж., Менк'ю Г., Стігліца Дж. [5], Тейлора М. Проте в переважній більшості праць публічні закупівлі розглядалися без урахування їх безпосередньої належності до електронного ринкового середовища.

Постановка завдання. Виходячи з вищесказаного, метою статті є дослідження сучасного стану і проблем розвитку системи публічних закупівель як базового інструмента B2G в Україні та світі.
Виклад основного матеріалу дослідження. За даними щорічного звіту за результатами дослідження "Глобального індексу мережевої взаємодії у 2020 році" (Global Connectivity Index, GCI), яке проводиться для аналізу ІКТ-інфраструктури та цифрової трансформації, Україна займає 52 місце серед 79 країн світу, котрі генерують 95\% світового ВВП. 3 таким показником вона належить до країнранніх адоптерів цифрової економіки [6]. Рейтинг нашої держави за Індексом мережевої готовності (Networked Readiness Index), який відображає інноваційний і технологічний потенціал країн світу, а також можливості їх розвитку в сфері високих технологій та цифрової економіки у 2020 р., - 64 місце зі 134 країн [7].

За визначенням британського журналу The Economist цифрова економіка - це економіка, що здатна забезпечити високоякісну IKTінфраструктуру та мобілізувати можливості споживачів, бізнесу та держави [8].

Найбільш розвиненою складовою цифрової економіки є електронна комерція, а поєднання інтересів бізнесу та держави максимальною мірою відображається в функціонуванні системи (моделі) B2G.

B2G (від англ. "Business-to-Government" - бізнес для уряду; в окремих випадках В2А "Business-to-Administration" або "бізнес-дляадміністраціі”) - це форма бізнесових трансакцій з приводу купівлі-продажу товарів i послуг між суб'єктами комерційної господарської діяльності та урядовими організаціями. Основні відмінності B2G від інших систем електронної комерції проаналізовано в табл. 1 [9].

Комерційні структури можуть взаємодіяти 3 державними установами різними способами: орендувати приміщення, котрі перебувають у державній формі власності;

- орендувати обладнання в держави на засадах лізингу;

укладати концесійні угоди (договори на будівництво чи реконструкцію нерухомості, яка буде належати державі);

отримувати контракти від держави на постачання товарів і надання послуг (публічні закупівлі).

Суб'єкти господарювання-учасники В2G повинні відповідати вимогам, які встановлюють відповідні державні установи, а залученість їх до системи відіграє важливу роль у цілому світі (рис. 1) [10]. 
Herald of Lviv University of Trade and Economics. Economic Sciences. № 65, 2021

Таблиця 1

\begin{tabular}{|c|c|c|c|c|}
\hline \multicolumn{5}{|c|}{ Порівняльна характеристика основних систем електронної комерції } \\
\hline & $\mathrm{B} 2 \mathrm{~B}$ & $\mathrm{~B} 2 \mathrm{C}$ & B2G & $\mathrm{C} 2 \mathrm{C}$ \\
\hline Мета угоди & Для розвитку бізнесу & $\begin{array}{c}\text { Для особистих пот- } \\
\text { реб }\end{array}$ & $\begin{array}{c}\text { Для державних пот- } \\
\text { реб }\end{array}$ & $\begin{array}{c}\text { Для особистих пот- } \\
\text { реб }\end{array}$ \\
\hline $\begin{array}{l}\text { Середній бюджет } \\
\text { покупки }\end{array}$ & Великий & Невеликий & Великий & Невеликий \\
\hline Обсяг замовлень & Може бути значним & Невеликий & Значний & Незначний \\
\hline Кількість клієнтів & Обмежена & Значна & Обмежена & Значна \\
\hline Реклама і маркетинг & $\begin{array}{c}\text { Орієнтовані на пев- } \\
\text { ного клієнта }\end{array}$ & $\begin{array}{c}\text { Орієнтовані на нео- } \\
\text { бмежену кількість } \\
\text { клієнтів }\end{array}$ & $\begin{array}{c}\text { Орієнтовані на інфо- } \\
\text { рмування державних } \\
\text { замовників }\end{array}$ & $\begin{array}{c}\text { Орієнтовані на нео- } \\
\text { бмежену кількість } \\
\text { клієнтів }\end{array}$ \\
\hline
\end{tabular}

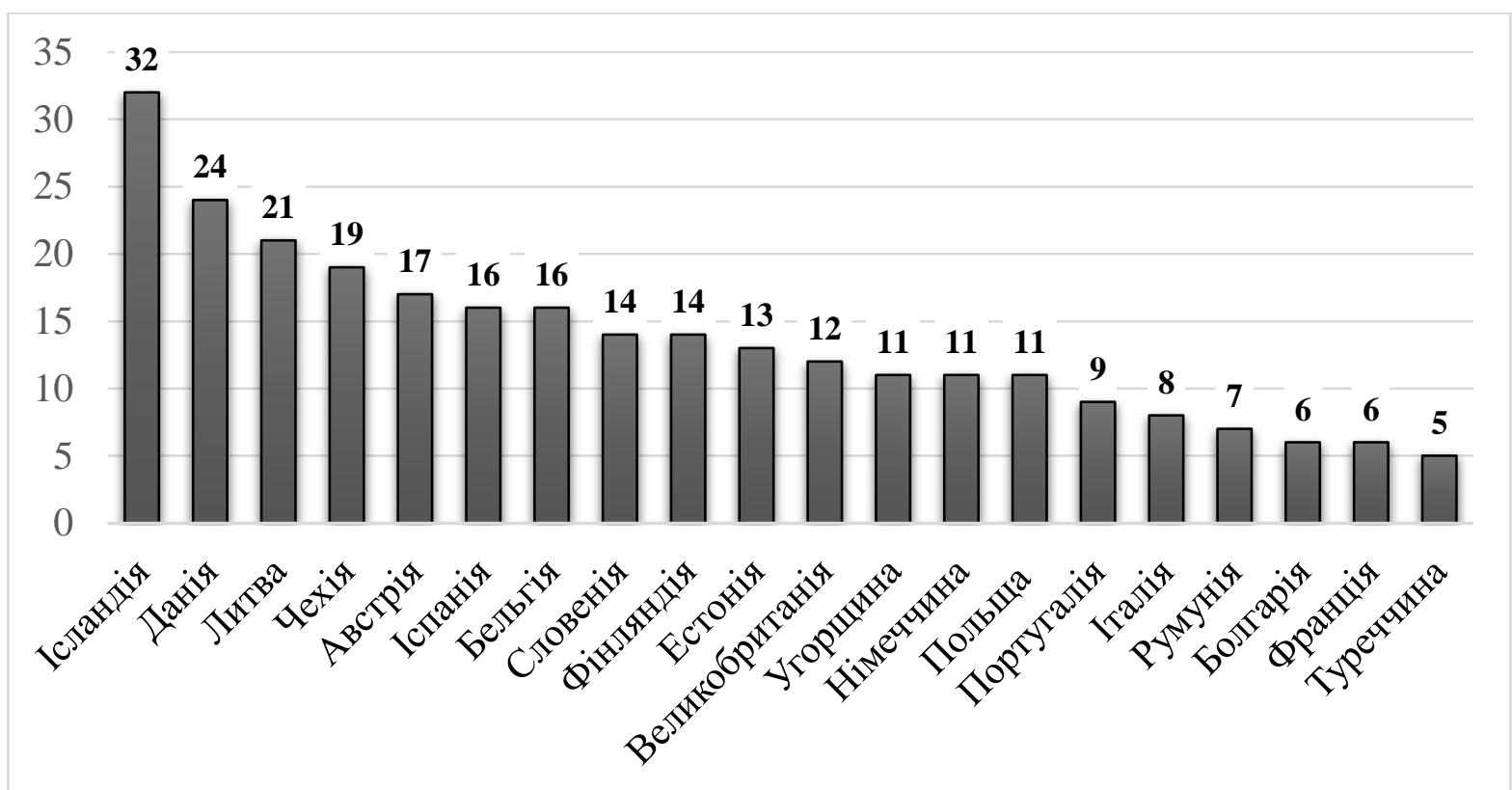

Рис. 1. Частка підприсмств, які були задіяні в B2G-системі електронної комерції у 2020 р.

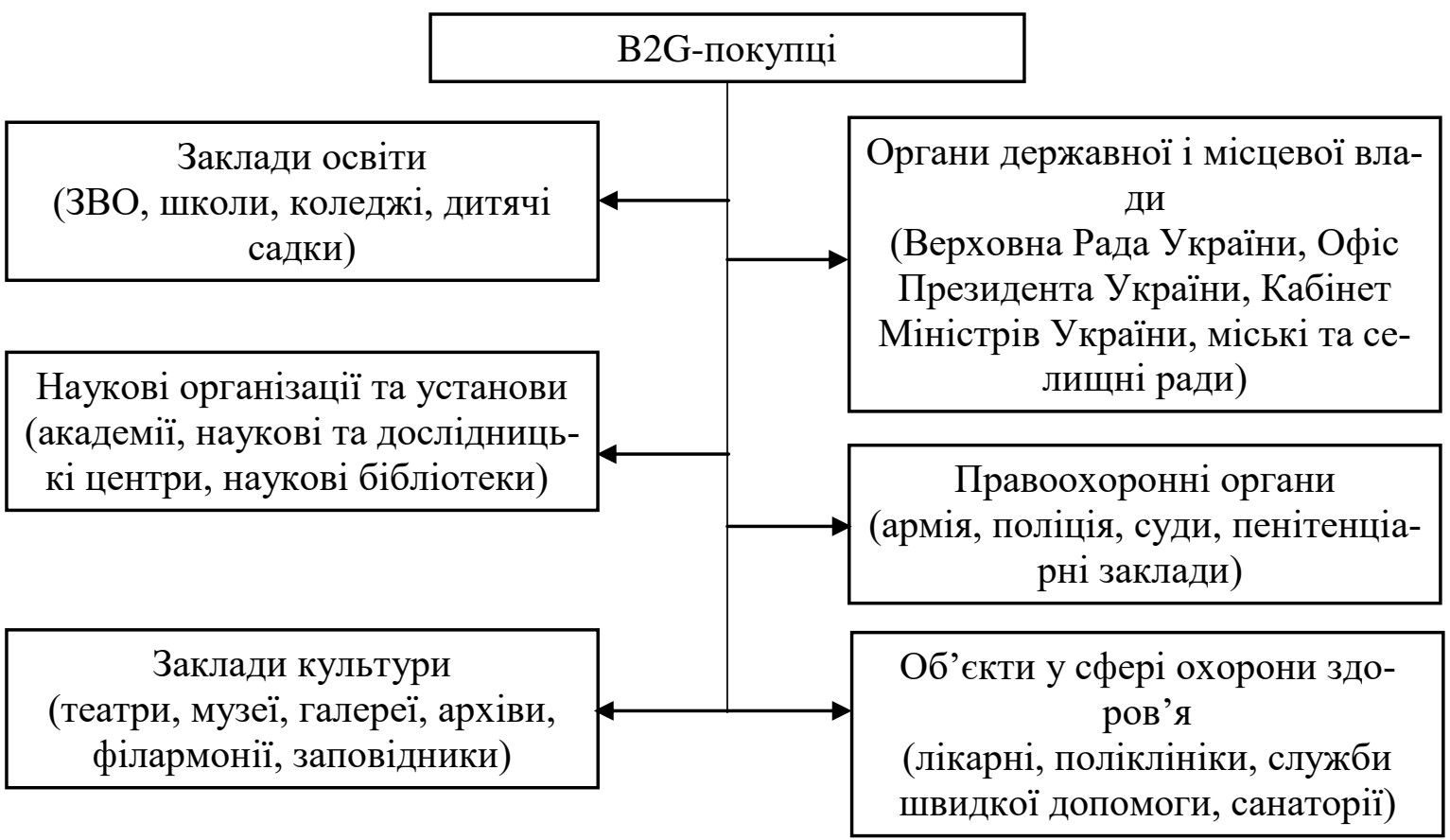

Рис. 2. Основні категорії покупців у системі B2G в Україні 
Водночас цей сегмент бізнесу вимагає максимальної відповідальності, оскільки неправильна організація процесу може зашкодити репутації компанії та її подальшим діловим зв'язкам.

Покупцями в системі B2G можуть бути різноманітні структури, що підпорядковуються та перебувають у сфері прямого впливу держави (рис. 2).

Серед основних особливостей системи $\mathrm{B} 2 \mathrm{G}$ можна назвати такі моменти:

- комерційні зв'язки обов'язково формуються на договірних засадах, а сам договір найчастіше укладається на конкурсній основі;

- механізм прийняття рішень досить складний і багаторівневий;

- уряд та державні установи здійснюють одноразові, переважно великі закупівлі;

- процеси оплати й обліку фінансів є достатньо складними;

- якщо постачальник не виконує свої зобов'язання (недотримання умов поставки, постачання неякісного товару тощо), на нього можуть накладатися певні санкції;

- значну, а часто і ключову роль у виборі постачальника відіграє вартість його продукції.

B2G-угоди укладаються в кілька етапів під контролем спеціалістів, котрі забезпечують контроль потреб держзамовника, пошук клієнтів серед адміністративних установ, дотримання всіх пунктів угоди, точне виконання платіжних операцій.

Наймасштабнішою складовою системи B2G $є$ публічні (державні) закупівлі. Так, за даними Світового банку (World Bank), вони складають приблизно 10-15\% світового ВВП [11]. У США обсяги закупівель, які щорічно здійснює уряд через державні сайти електронної комерції за федеральним графіком поставок (federal supply schedule - FSS), перевищують 1,5 млрд дол.

Загалом під закупівлею розуміють процес пошуку, узгодження умов і придбання товарів, послуг або робіт із зовнішнього джерела, часто шляхом проведення тендерів або конкурсних торгів.

Публічні закупівлі - це придбання замовником товарів, робіт і послуг у порядку, встановленому законодавством. В Україні з метою врегулювання сучасної системи публічних закупівель 25 грудня 2015 р. було прийнято Закон України "Про публічні закупівлі” №922-VIII. Це було обумовлено приєднанням нашої держави до Угоди СОТ про державні закупівлі (Agreement on Government Procurement, GPA/133) і необхідністю виконання міжнародних угод у сфері публічних закупівель шляхом адаптації вітчизняного законодавства до стандартів ЄС. Як наслідок, у 2016 р. в дію було введено електронну систему публічних закупівель ProZorro (з 12 лютого 2015 р. вона працювала в тестовому режимі), яка $3 \quad 1$ квітня стала обов'язковою для центральних органів влади, а 31 серпня - для всіх інших державних замовників. У порівнянні з 2015 р. у 2016 р. обсяг державних закупівель, розрахований як сумарна вартість укладених договорів, зріс на 17\%. Загалом у 2016 р. 3 їі використанням було здійснено 366,5 тис. закупівель на загальну суму майже 275 млрд грн, середня кількість пропозицій, яка припадала на одні торги, $-2,45$. За цей же період було завершено 101,7 тис. процедур закупівель, що підпадали під дію ЗУ “Про публічні закупівлі” (сума укладених договорів за процедурами перевищила 234 млрд грн). Вже наступного 2017 р. кількість проведених закупівель (за результатом яких було укладено договори) зросла більш ніж у 2 рази (до 869,3 тис.), а їх вартість у 1,8 рази, склавши 500 млрд грн [12].

Слід зауважити, що Закон України "Про публічні закупівлі" за період своєї дії зазнав численних змін, зокрема щодо уточнень предмета закупівель, кваліфікаційних критеріїв та інших вимог до учасників, оприлюднення інформації, організаційних процедур окремих типів закупівель, укладання договору про закупівлю та модифікації процедури оскарження. Поточна редакція діє від 10 листопада 2021 p.

У відповідності зі згаданим вище Законом України "Про публічні закупівлі" електронна система закупівель - це інформаційнотелекомунікаційна система, яка має комплексну систему захисту інформації з підтвердженою відповідністю згідно із Законом України "Про захист інформації в інформаційно-телекомунікаційних системах", що забезпечує проведення закупівель, створення, розміщення, оприлюднення, обмін інформацією і документами в електронному вигляді, до складу якої входять веб-портал Уповноваженого органу, авторизовані електронні майданчики, між якими забезпечено автоматичний обмін інформаці$є ю$ та документами. Уповноважений орган центральний орган виконавчої влади, що забезпечує формування та реалізує державну політику в сфері публічних закупівель. Функції Уповноваженого органу було покладено на Міністерство економічного розвитку і торгівлі України (з 2019 р. Міністерство економіки, торгівлі та сільського господарства України, а 3 травня 2021 р. - Міністерство економіки України).

У межах реалізації програми підвищення рівня професіоналізації у 2016 р. було створено базу знань для суб'єктів сфери публічних закупівель, яка поєднала в собі три складові:

1. Державний безкоштовний онлайн-курс "Публічні закупівлі” для спеціалістів-замовників, розділений на базовий і поглиблений рівні.

2. Інформаційний ресурс, створений Уповноваженим органом і розміщений на офіційному вебсайті Мінекономрозвитку, на якому надавалися онлайн-консультації суб'єктам сфери публічних закупівель.

3. Методичні матеріали, розміщені на інтернетpecypci http:// infobox.prozorro.org: понад 35 роз'яснювальних статей, 4 онлайн-курси самопідготовки (за час роботи ресурсу їх пройшли більш ніж 3 тис. користувачів), бібліотека 3230 примірних специфікацій різноманітних товарів.

Мета системи ProZorro - зробити процес використання державних коштів прозорим та ефективним, а корупційні схеми в публічних закупівлях неможливими. 3 цією метою у 2016 р. продовжувався розвиток модуля аналітики http://bi.prozorro.org, a також було створено моніторинговий портал Dozorro, що давав можливість всім бажаючим відслідковувати підозрілі закупівлі і повідомляти про них. Крім того, в листопаді цього ж року було 
запущено сестринський проект ProZorro ProZorro.Продажі, платформу для продажу майна неплатоспроможних банків та держпідприємств.

Також у межах Проєкту “Підтримка впровадження в Україні Угоди СОТ про державні закупівлі та розбудова спроможності українських постачальників" на інформаційному ресурсі про публічні закупівлі Інфобокс. ProZorro було створено розділ "Міжнародні тендери GPA" (https://infobox.prozorro.org/ gpa), призначений для надання практичної допомоги вітчизняному бізнесу стосовно участі у публічних закупівлях за межами України, насамперед у країнах-сторонах Угоди СОТ "Про державні закупівлі”.
Однією $з$ переваг електронної системи публічних закупівель стала можливість економії бюджетних коштів завдяки відкритості даних у системі та простоті участі у публічних закупівлях, що забезпечує конкуренцію на торгах. Економія розраховується як різниця між очікуваною вартістю закупівлі та сумою укладеного договору. Загальна економія бюджетних коштів у закупівлях, що успішно завершилися в 2016 р., склала близько 10 млрд грн, а вже у 2017 р. - понад 27 млрд грн.

Слід зазначити, що вітчизняна система електронних закупівель створювалася як аналог платформ, що ефективно функціонують у країнах СOT (табл. 2) [13].

Національні платформи публічних закупівель

Таблиия 2 окремих країн-членів угоди СОТ про державні закупівлі

\begin{tabular}{|c|c|c|c|}
\hline $\begin{array}{l}\text { № } \\
\text { 3/ח }\end{array}$ & Країна & Платформа & Електронна адреса платформи \\
\hline 1 & $\mathrm{EC}$ & TED (Tenders Electronic Daily) & http://ted.europa.eu/ \\
\hline 2 & Канада & Buy and Sell Canada & https://buyandsell.gc.ca \\
\hline 3 & Австрія & $\begin{array}{c}\text { Federal Procurement Agency (FPA), } \\
\text { ASFINAG, ÖBB Holding AG }\end{array}$ & $\begin{array}{l}\text { http://www.bbg.gv.at/ } \\
\text { https://www.auftrag.at/ } \\
\text { https://www.provia.at/ }\end{array}$ \\
\hline 4 & Фінляндія & Hensel & $\begin{array}{c}\text { www.hansel.fi } \\
\text { https://www.hankintailmoitukset.fi/ } \\
\text { https://tarjouspalvelu.fi/ } \\
\text { https://hanki.tarjouspalvelu.fi/ }\end{array}$ \\
\hline 5 & Франція & Plate-forme des Achats de l'Etat & $\begin{array}{l}\text { https://www.marches-publics.gouv.fr/ } \\
\text { https://www.marches-publics.info/ }\end{array}$ \\
\hline 6 & Німеччина & Organisation des Beschaffungsamtes & $\begin{array}{c}\text { http://www.bescha.bund.de/ } \\
\text { https://vergabe.hilgmbh.de/ } \\
\text { https://vergabeplattform.bwi.de/ } \\
\text { https://www.subreport-elvis.de/ } \\
\text { https://www.dtvp.de/ } \\
\text { https://www.evergabe-online.de/ } \\
\text { https://vergabekooperation.berlin/ }\end{array}$ \\
\hline 7 & Італія & $\begin{array}{c}\text { Il Programma per la razionalizzazione degli } \\
\text { Acquisti (The Program for the Rationalization } \\
\text { of Public Authority Purchases) }\end{array}$ & $\begin{array}{c}\text { https://www.acquistinretepa.it/ } \\
\text { https://www.consip.it/ } \\
\text { https://portaleacquisti.gruppoiren.it/ } \\
\text { https://intercenter.regione.emilia-romagna.it/ } \\
\text { https://www.ariaspa.it/ } \\
\text { https://albi.adspmaredisardegna.it }\end{array}$ \\
\hline 8 & Нідерланди & TenderNed & $\begin{array}{l}\text { https://www.tenderned.nl } \\
\text { https://portal.negometrix.com/ } \\
\text { https://eu.eu-supply.com/ }\end{array}$ \\
\hline 9 & Англія & gov.uk & $\begin{array}{c}\text { https://www.gov.uk/contracts-finder } \\
\text { https://www.gov.uk/digital-marketplace-sellers } \\
\text { https://www.procure-plus.com/ } \\
\text { https://procontract.due-north.com/ }\end{array}$ \\
\hline 10 & Японія & Jetro & https://www.jetro.go.jp \\
\hline 11 & $\begin{array}{l}\text { Чеська Респуб- } \\
\text { ліка }\end{array}$ & Vestnik & $\begin{array}{c}\text { https://www.vestnikverejnychzakazek.cz/ } \\
\text { http://www.isvz.cz/ } \\
\text { https://nen.nipez.cz/ } \\
\text { https://tenderarena.cz/ } \\
\text { https://ezak.cz/ } \\
\text { https://fen.cz/https://fen.cz/ }\end{array}$ \\
\hline 12 & Естонія & E-procurement Estonia & https://riigihanked.riik.ee \\
\hline 13 & Польща & Urzad Zamowien Publicznych & http://www.uzp.gov.pl/ \\
\hline 14 & Ізраїль & Government Pprocurment Administration & https://mr.gov.il/ \\
\hline 15 & США & FedBizOps & $\begin{array}{c}\text { https://www.fbo.gov/ } \\
\text { https://fbohome.sam.gov/ } \\
\text { https://www.acquisition.gov/ } \\
\text { https://www.fsd.gov/fsd-gov/home.do }\end{array}$ \\
\hline
\end{tabular}


У 2016 p. ProZorro отримала визнання на міжнародному рівні: українська система була визнана СБРР як рекомендована модель для впровадження в інших країнах. У травні 2016 р. у Лондоні вона отримала міжнародну премію у сфері закупівель World Procurement Awards 2016 в номінації "Публічний сектор за створення і впровадження електронної системи 3 унікальною архітектурою”. У грудні того ж року в Парижі систему ProZorro визнано найкращою в світі ініціативою відкритого урядування та було нагороджено міжнародною премією Open Government Awards 2016, яка відзначає громадські ініціативи, що покращують життя громадян на державному рівні. Крім того, 2020 р. вона була визнана найбільш прозорою системою публічних закупівель року за версією Transparent Public Procurement Rating [14].

Сучасна система електронних публічних закупівель складається з веб-порталу ProZorro й авторизованих електронних майданчиків, між якими забезпечено автоматичний обмін інформацією та документами. Портал забезпечує відкритий доступ до бази даних тендерів та надає послугу проведення редукціону (аукціону, в якому кроки здійснюються на зниження ціни і котрий є стандартним способом проведення відкритих тендерних закупівель за процедурою допорогових закупівель, відкритих торгів, конкурентного діалогу).

Технічне ядро системи складається з інструментарію OpenProcurement: Центральної бази даних (ЦБД) й API. OpenProcurement $\epsilon$ інструментарієм для електронних закупівель 3 відкритим кодом, i він уперше був застосований для ProZorro 3 використанням стандарту відкритих даних - Open Contracting Data Standard.

Учасники системи - замовники та постачальники - працюють на електронних майданчиках. На сьогоднішній день система об'єднує більш ніж 35 тис. державних та комунальних органів влади i підприємств, які виступають замовниками товарів, робіт і послуг, та майже 250 тис. комерційних компаній-постачальників. Обов'язки щодо забезпечення функціонування та наповнення системи покладено на власника системи - ДП "Прозорро". ДП "Прозорро" разом із електронною системою ProZorro належать державі Україна та підпорядковуються Кабінету Міністрів України.

Схема взаємодії замовників і постачальників через систему ProZorro представлена на рис. 3 .

Насамперед замовник через власний кабінет розміщує оголошення про закупівлю (тендер) на майданчику, де він зареєстрований (1). До оголошення потрібно прикріпити тендерну документацію, в якій прописуються кваліфікаційні критерії, характеристика предмета закупівлі, критерії оцінки тендерних пропозицій. Це оголошення передається 3 майданчика до центральної бази даних (2), у якій відбуваються трансакції та зберігається вся інформація, а $з$ неї - до інших майданчиків (3). Відповідно, потенційний постачальник, який планує взяти участь у тендері, через власний кабінет розміщує свою пропозицію на тому майданчику, де він зареєстрований (4). При прийманні пропозиції засекреченими залишаються як імена учасників, так і іiі вартість. Пропозиція, як і оголошення про закупівлю, також передається до ЦБД (5), а потім - на інші майданчики порталу. В подальшому інформація про вартість розкривається, однак імена учасників, як і раніше, залишаються засекреченими. 3 метою усунення конкурентів учасники максимально знижують розцінки на свою продукцію (роботи, послуги). Учасник із найнижчою ставкою може робити тендерну пропозицію в раунді останнім. Якщо компанія-переможець здатна виконати умови угоди, то $з$ нею укладається договір. Після цього з тендером можуть ознайомитися всі бажаючі.

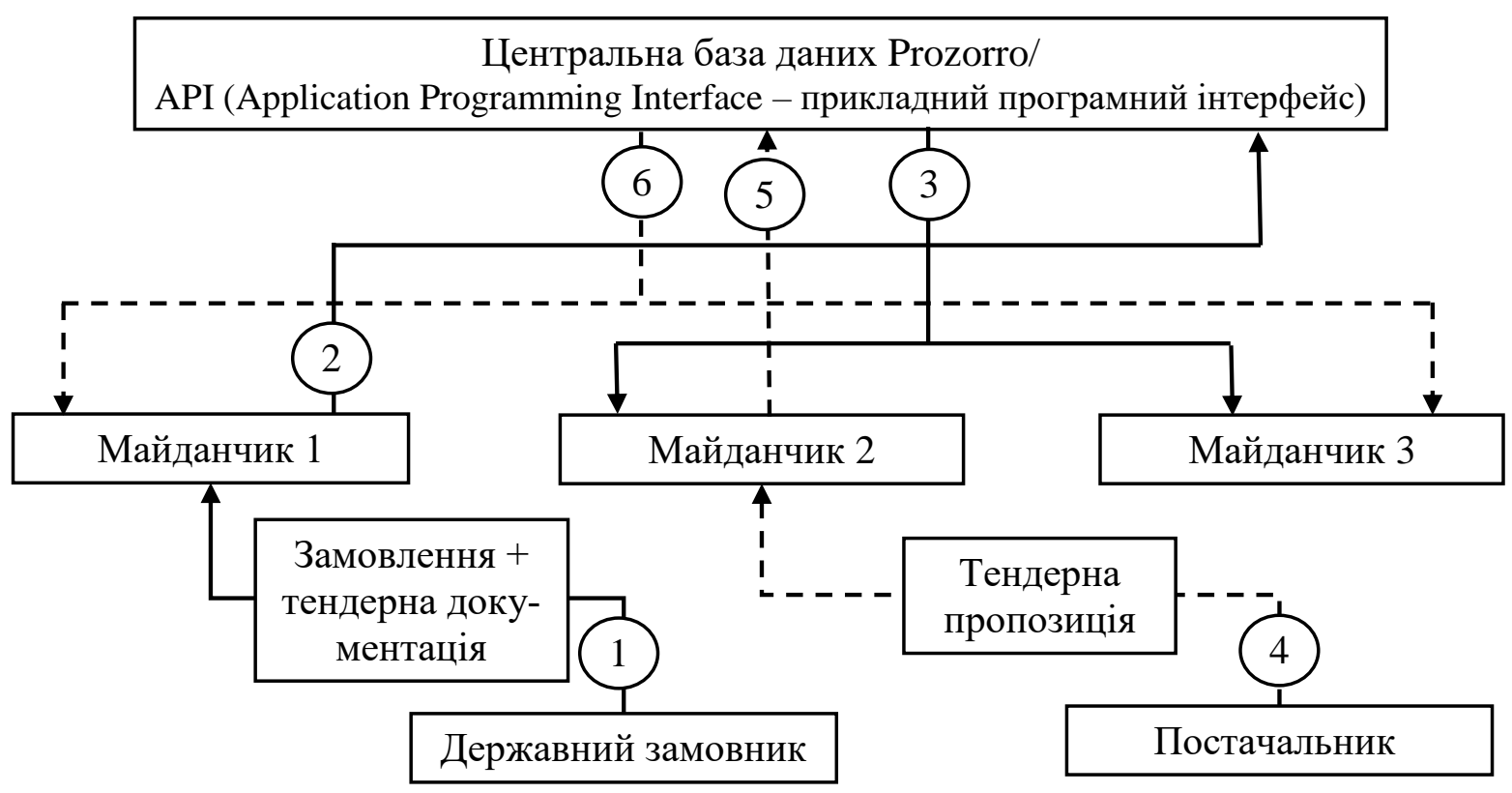

Рис. 3. Схема функціонування електронної системи публічних закупівель ProZorro 
Принцип функціонування електронної системи, при якому інформація через ЦБД оприлюднюється одночасно на порталі та всіх його майданчиках, називають гібридним або дворівневим.

Слід підкреслити, що дані Єдиної системи електронних закупівель є дозволеними для їх подальшого вільного використання та поширення: будьяка особа може вільно копіювати, публікувати, поширювати, використовувати (зокрема, в комерційних цілях), у поєднанні з іншою інформацією або шляхом включення до складу власного продукту, публічну інформацію у формі відкритих даних із обов'язковим посиланням на джерело отримання такої інформації.

Моніторинг системи публічних закупівель $\epsilon$ можливим завдяки модулю візуалізації та агрегації даних (BI) на базі програмного забезпечення QlikView. Існують дві версії модуля: публічний (вільний доступ) і професійний (необхідна ліцензія для користування). Функціонал обох модулів передбачає візуалізацію даних ЦБД у зручному для користувачів форматі, але лише професійний модуль дозволяе користувачам завантажувати дані. Кожна версія модуля $\epsilon$ інтерактивною онлайнсистемою звітності, де користувачі можуть перевіряти узагальнені результати публічних закупівель, а також досліджувати закупівлі більш детально, використовуючи інтуїтивну систему drag-and-drop.

Усі 13 авторизованих електронних майданчиків працюють за єдиними тарифами та процедурами, проте суттєво відрізняються за рівнями акредитації, зручністю роботи, рівнем сервісу та переліком додаткових послуг. Їх характеристики наведені в табл. 3.

Таблиця 3

Особливості функціонування авторизованих електронних майданчиків Сдиної системи електронних закупівель ProZorro

\begin{tabular}{|c|c|c|c|c|}
\hline $\begin{array}{l}\text { № } \\
\text { 3/ח }\end{array}$ & Майданчик & $\begin{array}{l}\text { Організатор } \\
\text { майданчика }\end{array}$ & $\begin{array}{l}\text { Рівні акреди- } \\
\text { тації }\end{array}$ & Функціональні особливості майданчика \\
\hline 1 & 2 & 3 & 4 & 5 \\
\hline 1 & Zakupki.prom.ua & $\begin{array}{l}\text { ТОВ “ЗАКУП- } \\
\text { КИ.ПРОМ.УА" }\end{array}$ & $\mathrm{I}-\mathrm{V}$ & $\begin{array}{l}\text { - безкоштовне навчання (вебінари, відеокур- } \\
\text { си, тренажер аукціону); } \\
\text { - перевірка замовника та постачальника за } \\
\text { відгуками і рейтингом; } \\
\text { - мобільний додаток. } \\
\end{array}$ \\
\hline 2 & SmartTender.biz & ТОВ “СМАРТТЕНДЕР” & $\mathrm{I}-\mathrm{V}$ & $\begin{array}{l}\text { - індивідуальні звіти та аналітика конкурен- } \\
\text { тів; } \\
\text { - можливість підписання КЕП кожного до- } \\
\text { кумента в тендерній пропозиції; } \\
\text { - замовлення довідок МВС онлайн та видача } \\
\text { до 2-х днів. }\end{array}$ \\
\hline 3 & $\underline{\text { GOV.AUCTION }}$ & $\begin{array}{l}\text { ТБ “ПУБЛІЧНІ АУКЦІО- } \\
\text { НИ” }\end{array}$ & I-IV & $\begin{array}{l}\text { - індивідуальні зустрічі з питань користуван- } \\
\text { ня майданчиком. }\end{array}$ \\
\hline 4 & IZI.TRADE & ТОВ “ІЗІ.Трейд” & II, IV & $\begin{array}{l}\text { - персональний менеджер; } \\
\text { - відтермінування платежу; } \\
\text { - індивідуальні доопрацювання системи під } \\
\text { потреби клієнтів. }\end{array}$ \\
\hline 5 & Newtend & ТОВ “НЬЮТЕНД” & I-IV & $\begin{array}{l}\text { - пошук та аналітика з вивантаженням даних } \\
\text { в Excel; } \\
\text { - нотифікації; } \\
\text { - вайбер-бот. }\end{array}$ \\
\hline 6 & $\underline{\text { PlayTender }}$ & ТОВ “Плейтендер” & I-IV & $\begin{array}{l}\text { - реєстрація за допомогою КЕП без укладан- } \\
\text { ня договорів; } \\
\text { - онлайн-оплата та відстрочки платежу; } \\
\text { - наявність банківських гарантій. }\end{array}$ \\
\hline
\end{tabular}


Вісник Львівського торговельно-економічного університету. Економічні науки. № 65, 2021

\begin{tabular}{|c|c|c|c|c|}
\hline & & & & Продовження табл. 3 \\
\hline 1 & 2 & 3 & 4 & 5 \\
\hline 7 & ТЕНДЕР - online & ПП “ТЕНДЕР ОНЛАЙН” & $\mathrm{I}-\mathrm{V}$ & $\begin{array}{l}\text { - сертифікат комплексної системи захисту } \\
\text { інформації; } \\
\text { - послуги персонального менеджера; } \\
\text { - особливі тарифи від банка-партнера на бан- } \\
\text { ківські гарантії. }\end{array}$ \\
\hline 8 & Zakupivli24 & АТ КБ “ПРИВАТБАНК” & $\begin{array}{l}\text { I- } \\
\text { IV }\end{array}$ & $\begin{array}{l}\text { - реєстрація за допомогою КЕП без укладан- } \\
\text { ня договорів; } \\
\text { - онлайн-оплата та відстрочки платежу. }\end{array}$ \\
\hline 9 & E-tender & ТОВ “Е-Тендер" & $\begin{array}{l}\text { I- } \\
\text { IV }\end{array}$ & $\begin{array}{l}\text { - персональний менеджер для постачальни- } \\
\text { ків; } \\
\text { - індивідуальна аналітика по власній участі, } \\
\text { конкурентах, ринках; } \\
\text { - повідомлення у Вайбер і Телеграм; } \\
\text { - безкоштовна участь у комерційних закупів- } \\
\text { лях. }\end{array}$ \\
\hline 10 & $\begin{array}{c}\text { Держзакупівлі. } \\
\text { Онлайн }\end{array}$ & $\begin{array}{c}\text { TOB “Держзакупівлі. } \\
\text { Онлайн” }\end{array}$ & $\begin{array}{l}\text { I- } \\
\text { IV }\end{array}$ & $\begin{array}{l}\text { - безкоштовна юридична підтримка; } \\
\text { - безкоштовне навчання для клієнтів; } \\
\text { - наявність регіональних представництв. }\end{array}$ \\
\hline 11 & $\frac{\text { Українська універсаль- }}{\underline{\text { на біржа }}}$ & $\begin{array}{c}\text { TOB "Українська універсаль- } \\
\text { на біржа" }\end{array}$ & $\begin{array}{l}\text { I- } \\
\text { IV }\end{array}$ & $\begin{array}{l}\text { - телеграм-бот; } \\
\text { - наявність регіональних представників; } \\
\text { - аналітика тендерів та учасників. }\end{array}$ \\
\hline 12 & Public Bid & ТОВ “ІТ Контракт” & \begin{tabular}{|l} 
I- \\
IV
\end{tabular} & $\begin{array}{l}\text { - додаткові сервіси; } \\
\text { - пошук за оскарженням (вимогами); } \\
\text { - підписка. }\end{array}$ \\
\hline 13 & zakupki.com.ua & ТОВ “ЗАКУПІВЛІ:ЮА” & $\begin{array}{l}\text { I- } \\
\text { IV }\end{array}$ & $\begin{array}{l}\text { - прогноз переможної ціни та конкурентів на } \\
\text { аукціоні; } \\
\text { - щотижневі вебінари та інструкції, індивіду- } \\
\text { альне навчання. }\end{array}$ \\
\hline
\end{tabular}

Правила торгів на електронних майданчиках уніфіковані, тобто однакові для всіх, незалежно від того, який саме майданчик був обраний. Ймовірність шахрайства чи змови мінімізована, оскільки торги проводяться відкрито, а учасники приховані за допомогою цифрових позначень. Дізнатися про те, хто саме переміг в аукціоні, його організатор зможе лише після того, як торги завершаться. Крім традиційних аукціонів на підвищення ціни, в системі ProZorro також є аукціони, створені на основі голландської моделі - на пониження ціни. Завдяки цьому можна швидко розпродати проблемні активи, що не були продані на звичайних торгах. За всіма аукціонами можна спостерігати в режимі реального часу, і вдень, і вночі.

Сучасний стан розвитку вітчизняних публічних закупівель можна проаналізувати за допомогою комплексу показників (табл. 4) [7].

Від початку роботи електронної системи закупівель до 1 січня 2021 р. оголошено 7,7 млн процедур із очікуваною вартістю 4,3 трлн грн, із яких кількість успішно завершених перевищує 7 млн 3 очікуваною вартістю 2,8 трлн грн. Загалом кількість завершених тендерів у 2020 р. в порівнянні 3 2019 р. збільшилася у 2,8 рази, а кількість лотів практично в 3 рази. Найчастіше у 2020 р. організатори закуповували товари (67,8\% всіх завершених закупівель), у той час як на послуги припало лише $26,2 \%$, а на закупівлі робіт - лише $6 \%$ [12].

Порівняно $з$ попереднім роком кількість активних замовників зросла на 23,8\% і склала 37,9 тис. Найбільша їх кількість була зосереджена в Київській, Дніпропетровській, Львівській, Донецькій та Одеській областях. При цьому 23,55\% замовників протягом року провели від 1 до 10 закупівель, $11,27 \%$ - від 11 до 20 закупівель, від 20 до 100 закупівель було проведено $36,34 \%$ замовниками і більше 100 закупівель на рік провели 28,85\% замовників [7]. Водночас зросла і кількість учасників, що свідчить про зменшення бар'єрів для участі у публічних закупівлях та підвищення довіри представників бізнесу до процесу публічних закупівель. 


\section{Herald of Lviv University of Trade and Economics. Economic Sciences. № 65, 2021}

Табличяя 4

Результати функціонування системи електронних публічних закупівель в Україні у 2020 р.

\begin{tabular}{|c|c|c|c|c|c|}
\hline Метод закупівель & $\begin{array}{l}\text { Кількість тен- } \\
\text { дерів, тис. }\end{array}$ & $\begin{array}{c}\text { Кількість унікаль- } \\
\text { них учасників, } \\
\text { тис. }\end{array}$ & $\begin{array}{c}\text { Очікувана } \\
\text { вартість } \\
\text { лотів, млрд } \\
\text { грн }\end{array}$ & $\begin{array}{c}\text { Середня кількість } \\
\text { пропозицій } \\
\text { на торги }\end{array}$ & $\begin{array}{c}\text { Сума } \\
\text { договорів, } \\
\text { млрд грн }\end{array}$ \\
\hline $\begin{array}{l}\text { Процедура звітування про } \\
\text { укладений договір }\end{array}$ & 3062,6 & 221,6 & 111,548 & - & 111,026 \\
\hline Переговорна процедура & 30,9 & 11,4 & 63,189 & - & 58,842 \\
\hline $\begin{array}{l}\text { Переговорна процедура за } \\
\text { нагальною потребою }\end{array}$ & 29,6 & 3,5 & 34,808 & - & 31,403 \\
\hline $\begin{array}{l}\text { Переговорна процедура (для } \\
\text { потреб оборони) }\end{array}$ & 2,2 & 1,7 & 19,523 & 2,42 & 17,083 \\
\hline Відкриті торги & 91,1 & 41,4 & 159,461 & 2,76 & 142,304 \\
\hline $\begin{array}{l}\text { Відкриті торги з публікацією } \\
\text { англійською мовою }\end{array}$ & 7,9 & 10,1 & 288,151 & 3,13 & 259,437 \\
\hline Електронні каталоги & 6,7 & - & 0,099 & - & 0,099 \\
\hline $\begin{array}{l}\text { Закупівля за рамковою уго- } \\
\text { дою }\end{array}$ & 0,4 & 0,1 & 6,057 & 4,88 & 5,231 \\
\hline Допорогова закупівля & 74,3 & - & 19,037 & - & 17,034 \\
\hline Спрощені закупівлі & 110,3 & 35,6 & 18,242 & - & 16,148 \\
\hline $\begin{array}{l}\text { Звіт про укладений договір } \\
\text { (COVID-19) }\end{array}$ & 129,2 & 11,9 & 27,181 & - & 26,627 \\
\hline Конкурентний діалог & 0,0 & 0,0 & 0,603 & 3,00 & 0,477 \\
\hline $\begin{array}{l}\text { Конкурентний діалог з публі- } \\
\text { кацією англійською мовою }\end{array}$ & 0,0 & 0,0 & 0,004 & 3,00 & 0,003 \\
\hline
\end{tabular}

Найбільшим джерелом фінансування публічних закупівель за сумою договорів $є$ Державний бюджет України - понад 198 млрд грн. (45,5\%). Місцеві бюджети складають понад 117 млрд грн (26,9\%) всього фінансування, власні бюджети (кошти від господарської діяльності підприємства) більш ніж 98 млрд грн (22,66\%) [12].

Протягом 2020 р. участь у публічних закупівлях України взяли 593 учасники 343 країн світу. Частка договорів, укладених із іноземними учасниками, від загальної кількості склала 0,02\% на суму понад 32 млрд грн. У топ-5 країн за кількістю укладених договорів входять Чехія, Великобританія, Польща, Німеччина та Швейцарія.

Економія коштів в закупівлях, що успішно завершились у 2020 р., перевищила 47,3 млрд грн, в той час як у 2019 р. цей показник був дещо більшим ніж 28 млрд. грн. Всього ж за 5 років існування системи бюджетна економія склала 150 млрд грн.

Як вже зазначалося, однією $з$ переваг електронної системи закупівель є іiі відкритість і транспарентність. Це полегшує контроль за нею не лише державним органам, але й громадському сектору. На сьогоднішній день існує достатньо громадських об'єднань і засобів масової інформації, які слідкують за ефективним використанням бюджетних коштів. У контексті нашого дослідження серед них слід виділити моніторинговий портал DoZorro (проєкт Transparency International Україна за підтримки Open Contracting Partnership, Omidyar Network, МФ “Відродження”, проекту "Прозорість і підзвітність у державному управлінні та послугах" (USAID, UKaid, Eurasia Foundation), а також EBRD's та Ukraine Stabilisation and Sustainable
Growth Multi-Donor Account (MDA)) і ГО "Платформа Громадський Контроль", партнерами якого є аналітична система для комплаєнсу, аналізу ринків, ділової розвідки та розслідувань YouControl, Представництво ЄС в Україні, Європейський фонд підтримки демократії (EED, European Endowment for Democracy) і проєкт $\mathrm{CC} \mathrm{"Антикорупційна} \mathrm{ініціати-}$ ва Європейського Союзу в Україні” (EUACI, EU Anti-Corruption Initiative).

Для відзначення кращих учасників сфери електронних публічних закупівель із 2016 р. щорічно вручається Всеукраїнська професійна премія ринку електронних торгів “Zakupki. Кращі”. Взяти участь у боротьбі за неї можуть як державні, так і комерційні компанії, а нагороди присуджуються в трьох номінаціях: "Громадський вибір”, “За результатами в системі” та "Експертний вибір”. У першій номінації суб'єкти господарювання можуть номінувати себе або партнерів, а переможців обирають відкритим голосуванням. Кращих у номінаціях “За результатами в системі" та "Експертний вибір" визначають представники майданчика-організатора премії Zakupki.Prom і порталу DoZorro. Цьогоріч нагородження проводилося 28 липня за результатами 2020 р. і вперше в категорії "Експертний вибір" було нагороджено замовника та постачальника, які найактивніше залишали відгуки про своїх партнерів на майданчику [16].

Також Zakupki.Prom.uа проводить наймасштабніший в Україні захід, який стосується державних і комерційних закупівель - Forum Zakupki. У 2021 р. він проходив в онлайн-форматі 6-7 квітня, його спікерами були 24 експерти, а учасники поділялися на два слоти: "Forum Zakupki: нова ера для 
замовників" i "Forum Zakupki: нова ера для постачальників" [17].

3 метою аналізу ефективності функціонування електронної системи публічних закупівель ProZorro Transparency International Україна проводилося дослідження "По той бік ProZorro: чи довіряє український бізнес публічним закупівлям”, для чого було опитано 599 учасників закупівель у системі [18].

За даними цього опитування, 54\% учасників загалом задоволені роботою системи ProZorro. Серед них $80 \%$ опитаних задоволені роботою в електронних майданчиках ProZorro, 70\% - зручністю пошуку тендерів, 79\% - подачею тендерних пропозицій. Крім того, 63\% підприємців були зареєстровані одразу на кількох майданчиках, що свідчить про високу конкуренцію майданчиків на ринку.

Разом 3 тим, 24\% опитаних стверджували, що безпосередньо стикалися з корупцією при роботі 3 системою ProZorro, у 19\% - стикалися їхні знайомі. При цьому 41\% вказали, що з корупцією в ProZorro не стикалися, причому цей показник був більшим на 9\%, аніж до появи електронної онлайн-системи.

Серед проблем, із якими бізнес найчастіше стикається в публічних закупівлях, опитані учасники назвали: дискримінаційні вимоги в тендерній документації (69,9\%), вимоги необов'язкових документів $(68,1 \%)$, безпідставне відхилення пропозиції (55,8\%). 84\% опитаних вважали, що відповідальність і покарання замовників за порушення у сфері публічних закупівель необхідно посилити.

Висновки і перспективи подалыших досліджень у даному напрямі. В процесі історичного й економічного розвитку суспільства сформувалися стійкі та різноманітні типи взаємозв'язків держави та бізнес-структур. Держава володіє економічними, силовими й інформаційними ресурсами, а бізнес організаційними, фінансовими, експертними та інноваційними. Їх взаємодія забезпечує належний політичний, економічний i соціальний розвиток кожної країни. Застосування інформаційнокомунікаційних технологій у цьому випадку суттєво спрощує і підвищує якість цієї взаємодії.

Саме тому одним із найбільш перспективних напрямів розвитку електронної комерції $\epsilon$ електронні публічні закупівлі, які набули достатнього поширення в розвинених країнах світу. Впровадження аналогічної системи дало змогу українській державі увійти в глобальне правове та ринкове середовище, посилити боротьбу з корупцією, забезпечити справедливу та вільну конкуренцію завдяки збільшенню кількості постачальників та відкритості торгів, а також суттєву економію бюджетних коштів, проте не позбавило всіх проблем. Водночас процес розвитку та вдосконалення системи публічних закупівель триватиме і далі, що визначає потребу в їі подальших наукових та прикладних дослідженнях.

\section{ЛІТЕРАТУРА}

1. Альциванович О. В., Цимбаленко Я. Ю. Теоретико-категоріальний аналіз поняття публічних закупівель та корупційних ризиків при їх здійсненні в Україні. Аспекти публічного управління. 2018. Т. 6. № 9. C. 92-103.

2. Джабраїлов Р. А., Малолітнєва В. К. Публічні закупівлі як засіб державного регулювання господарської діяльності та реалізації цілей сталого розвитку. Право України. 2019. № 8. С. 47-64.

3. Мельников О. С. Особливості публічних закупівель як об'єкта державного регулювання економіки. Теорія та практика державного управління. 2016. Вип. 1. С. 129-135.

4. Сошніков А. О. Теоретичні засади здійснення публічних закупівель. Часопис Київського університету права. 2015. № 3. С. 221-226.

5. Stiglitz J., Rosengard J. K. Economics of the Public Sector. 3rd ed. New York : W.W. Norton. $960 \mathrm{p}$.

6. Нuawei опублікувала сьомий щорічний звіт Global Connectivity Index: п'ять основних етапів цифрової трансформації галузі. URL: https://cutt.ly/YT0aKsr.

7. Цифрова економіка та інформаційнокомп'ютерні технології. URL: https://cutt.ly/ 9T0aCdt.

8. Technology isn't working. The Economist. 2014. Oct 2nd. URL: https://cutt.ly/9T2xcMf.

9. Что такое В2В, В2С, B2G, С2C: обзор главных отличий, примеры + инструкция как грамотно организовать продажи в этих сферах. URL: https://cutt.ly/xT0aN19.

10. Share of enterprises making B2B and B2G ecommerce sales via a website in 2020 , by country. URL: https://www.statista.com/statistics/1196536.

11. WTO and government procurement. URL: http:// https://www.wto.org/english/tratop_e/ gproc_e/ gproc_e.htm.

12. Звіти сфери публічних закупівель. URL: https://cutt.ly/cT0a7es.

13. Національні платформи публічних закупівель країн-членів COT. URL: https://cutt.ly/uT0a61z.

14. Нагороди ProZorro. URL: https://prozorro.gov.ua/ about.

15. Майданчики ProZorro. URL: https://cutt.ly/ QT2bHo8.

16. Премія Zakupki.Кращі 2021: які компанії отримали нагороди. URL: https://cutt.ly/ST2bNFA https://cutt.ly/ST2bNFA.

17. Forum Zakupki: ви знатимете більше! URL: https://cutt.ly/1T0sazi.

18. По той бік Prozorro: чи довіряє український бізнес публічним закупівлям? URL: https://cutt.ly/RT0srwH.

\section{REFERENCES}

1. Al'tsyvanovych, O. V. and Tsymbalenko, Ya. Yu. (2018), Teoretyko-katehorial'nyj analiz poniattia publichnykh zakupivel' ta koruptsijnykh ryzykiv pry ikh zdijsnenni v Ukraini, Aspekty publichnoho upravlinnia, vol. 6, № 9, pp. 92-103.

2. Dzhabrailov, R. A. and Malolitnieva, V. K. (2019), Publichni zakupivli iak zasib derzhavnoho 


\section{Herald of Lviv University of Trade and Economics. Economic Sciences. № 65, 2021}

rehuliuvannia hospodars'koi diial'nosti ta realizatsii tsilej staloho rozvytku, Pravo Ukrainy, № 8, pp. 47-64.

3. Mel'nykov, O. S. (2016), Osoblyvosti publichnykh zakupivel' iak ob'iekta derzhavnoho rehuliuvannia ekonomiky, Teoriia ta praktyka derzhavnoho upravlinnia, issue 1, pp. 129-135.

4. Soshnikov, A. O. (2015), Teoretychni zasady zdijsnennia publichnykh zakupivel', Chasopys Kyivs'koho universytetu prava, № 3, pp. 221-226.

5. Stiglitz, J. and Rosengard, J. K. (2000), Economics of the Public Sector, 3 rd ed., W.W. Norton., New York, pp. 86-88.

6. Huawei opublikuvala s'omyj schorichnyj zvit Global Connectivity Index : p'iat' osnovnykh etapiv tsyfrovoi transformatsii haluzi (2020), available at: https://cutt.ly/YT0aKsr.

7. Tsyfrova ekonomika ta informatsijnokomp'iuterni tekhnolohii, available at: https://cutt.ly/9T0aCdt.

8. Technology isn't working (2014), The Economist, Oct 2, available at: https://cutt.ly/9T2xcMf.

9. Chto takoe B2B, B2C, B2G, C2C: obzor glavnyh otlichij, primery + instrukcija kak gramotno organizovat' prodazhi $\mathrm{v}$ jetih sferah, available at: https://cutt.ly/xT0aN19.

10. Share of enterprises making B2B and B2G e-commerce sales via a website in 2020 , by country, available at: https://www.statista.com/ statistics/1196536.

11. WTO and government procurement, available at: http:// https://www.wto.org/english/ tratop_e/gproc_e/gproc_e.htm.

12. Zvity sfery publichnykh zakupivel', available at: https://cutt.ly/cT0a7es.

13. Natsional'ni platformy publichnykh zakupivel' krain-chleniv SOT, available at: https://cutt.ly/uT0a61z.

14. Nahorody ProZorro, available at: https://prozorro.gov.ua/about.

15. Majdanchyky ProZorro, available at: https://cutt.ly/QT2bHo8.

16. Premiia Zakupki.Kraschi 2021: iaki kompanii otrymaly nahorody, available at: https://cutt.ly/ST2bNFA/

17. Forum Zakupki: vy znatymete bil'she!, available at: https://cutt.ly/1T0sazi.

18. Po toj bik Prozorro: chy doviriaie ukrains'kyj biznes publichnym zakupivliam?, available at: https://cutt.ly/RT0srwH.

Стаття надійила до редакиії 20 листопада 2021 року 